\title{
MANAJEMEN HUBUNGAN MASYARAKAT \\ DALAM MENINGKATKAN PARTISIPASI MASYARAKAT SEKITAR DI MA AT-TAHZIB KEKAIT GUNUNGSARI
}

\author{
Ahmad Sulhan \\ Universistas Islam Negeri (UIN) Mataram \\ Jl. Pendidikan No.35 Mataram \\ Email: ahmadsulhansaida@gmail.com
}

\begin{abstract}
Abstrak: Kegiatan manajemen hubungan masyarakat mencakup fungsi-fungsi pokok manajemen secara umum, berfungsi dan bertujuan menciptakan dan mengembangkan persepsi terbaik bagi suatu organisasi lembaga pendidikan yang kegiatannya langsung ataupun tidak langsung mempunyai dampak bagi masa depan organisasi lembaga pendidikan itu. Penelitian ini dilakukan untuk menggali dan menggambarkan "Manajemen Hubungan Masyarakat dalam Meningkatkan Partisipasi Masyarakat Sekitar di MA At-Tahzib Kekait Gunungsari" dengan tujuan untuk mengetahui bagaimana konsep manajemen hubungan masyarakat di MA At-Tahzib Kekait Gunungsari, bagaimana kondisi umum bentuk partisipasi masyarakat di MA At-Tahzib Kekait Gunungsari dan bagaimana model peran manajemen humas dalam meningkatkan partisipasi masyarakat sekitar di MA At-Tahzib Kekait Gunungsari. Jenis penelitian ini menggunakan pendekatan kualitatif, dan metode pengumpulan datanya menggunakan wawancara mendalam, observasi partisipan, dan dokumentasi. Kemudian data tersebut dianalisa dengan tiga tahap yaitu verifikasi data, display data dan reduksi data. Dari hasil penelitian ini menunjukkan bahwa konsep manajemen hubungan madrasah dengan masyarakat internal yang efektif memberikan konstribusi terhadap kelancaran hubungan madrasah dengan masyarakat eksternal. Melalui kebebasan berkomunikasi dilingkungan internal madrasah, semua warga madrasah mempunyai kesempatan yang sama untuk berkreasi dan mengeluarkan pendapat. Dengan demikian, lahirlah sejumlah kegiatan hubungan madrasah dengan masyarakat untuk menggalang partisipasi masyarakat. Kondisi umum bentuk partisipasi masyarakat melalui manajemen humas dimulai dengan perencanaan partisipatif dan pengorganisasian dalam bentuk panitia pelaksana dengan melibatkan semua unsur madrasah yang terkait. Proses selanjutnya adalah pengaktifan dalam bentuk komunikasi dan pelaksana kegiatan. Komunikasi yang paling akrab dilakukan madrasah dengan komite madrasah yang bertujuan menyerap aspirasi ide, dan kebutuhan masyarakat. Proses terakhir manajemen humas adalah pengendalian yang dilakukan terhadap proses kegiatan dan hasil kegiatan humas. Model peran manajemen humas dalam meningkatkan partisipasi masyarakat sekitar di MA At-Tahzib Kekait Gunungsari difasilitasi dan digalang oleh komite madrasah. Partisipasi masyarakat dalam bentuk pengambilan keputusan, pelaksanaan program, pengambilan manfaat,dan evaluasi.
\end{abstract}

Abstract: Public relations management activities cover the main functions of
management in general, functioning and aims to create and develop the best perception
for an organization of educational institution whose activities directly or indirectly have
an impact on the future of the educational institution organization. This research was
conducted to explore and describe "Public Relations Management in Increasing the
Participation of Surrounding People in MA At-Tahzib Kekait Gunungsari" with the aim
to know how is the concept of public relations management in MA At-Tahzib Kekait
Gunungsari; how are the general conditions of community participation in MA At -
Tahzib Kekait Gunungsari; and how is the role model of public relations management in 
increasing the participation of surrounding communities in MA At-Tahzib Kekait Gunungsari. This type of research uses a qualitative approach, and the method of data collection uses in-depth interviews, participant observation, and documentation. Then the data is analyzed in three stages namely data verification, data display and data reduction. The results of this study indicates that the concept of madrasah relationship management with an effective internal society contributes to the smoothness of madrasah relationships with external communities. Through the freedom of communication within the internal madrasah, all madrasah residents have the equal opportunity to be creative and to express their opinions. Thus, a number of madrasah relationship activities were established with the community to mobilize the community participation. The general condition of community participation's form through public relations management is begun with participatory planning and organizing in the form of the organizing committee by involving all elements of the related madrasah. The next process is the activation of communication form and executing activities. The most familiar communication of madrasahs with madrasah committees aimed at absorbing the aspirations of ideas, and the needs of society. The last process of public relations management is the control performed on the process of activities and the results of public relations activities. The role model of public relations management in increasing the participation of surrounding communities in MA At-Tahzib Kekait Gunungsari is facilitated and mobilized by the madrasah committee. While the community participations are shown in decision-making, program implementation, benefit-taking, and evaluation.

Kata Kunci: manajemen, humas, partisipasi, masyarakat

\section{PENDAHULUAN}

Manajemen hubungan masyarakat merupakan komunikasi dua arah antara organisasi dengan publik (masyarakat) secara timbal balik dalam rangka mendukung fungsi dan tujuan manajemen dengan meningkatkan pembinaan kerja sama serta pemenuhan kepentingan bersama. ${ }^{1}$

Hubungan masyarakat adalah fungsi manajemen yang berkelanjutan dan terarah lewat mana organisasi lembaga pendidikan negeri maupun swasta,berusaha mempertahankan pengertian, simpati,dan dukungan orang-orang yang mereka inginkan dengan menilaipendapat masyarakat di sekitar mereka sendiri, untuk kemudian dihubungkan sejauh mungkin dengan karsa dan tingkah lakunya, guna mencapai kerja sama lebih produktif dan lebih efisien untuk memenuhi kepentingan mereka bersama, dengan suatu informasi yang direncanakan dan disebar luaskan.

Cukup banyak definisi manajemen hubungan masyarakat yang dikemukakanoleh pakar, akademisi dan praktisi. Dan berbagai definisi tersebut,garis besarnya adalah manajemen hubungan masyarakat dapat dilihat secara konseptual, dan unsur-unsurnya dalam aktivitas atau kegiatan sertafaktor-faktor yang mempengaruhipengertian manajemen hubungan masyarakatdalam suatu organisasi. Baik untuk tujuan komunikasi

${ }^{1}$ Rosadi Ruslan, Manajemen Publik Relation dan Media Komunikasi (Jakarta: PT. Raja Grafindo Persada, 2005), 119. 
dua arahtimbal-balik, membangun hubungaan baik maupun komunikasi persuasive atau searah, yang pada akhirnya bertujuan untukmembangun saling pengertian, menghargai, dukungan yang baik hingga menciptakan citra positif.

Hubungan masyarakat merupakan bagian integral dalam suatu organisasi, bukan sekedar institusi komplementer yangberfungsi semacam parfum untuk membuat harum ruangan atausemacam lipstick agar kelihatan lebih cantik, bukan pula sekedar menciptakan citra seolah-olah kelihatan kuat, sehat, baik, dan sebagainya, tugas hubungan masyarakatjustru berusaha menciptakanagar organisasi madrasah kondusif, sungguh-sungguh sehat iklim kerjanya,kuat hubungan sosialnya,tinggi kinerja sumberdaya manusianya.

Sangat tidak benar jika suatu organisasi madrasah mendirikan hubungan masyarakat sekedar agar kelihatan berwibawa. Hubungan masyarakat bukan sekedar katalisator organisasi, dalam mana memacu reaksi tetapi tidak ikut bereaksi dalam urusan dari keseluruhan komposisi yang ada. Banyak orang tidak menyadari hal tersebut, sehingga memposisikan humas sebagai bagian organisasi yang berdiri sendiri, hidup sendiri, malahan tidak diberi akses untuk berhubungan dengan bagian yang lain. Top manager seringkali melihat atau memposisikan humas sekedar sebagai instrument, atau alat bagi organisasi bahkan individu-individu pemilik kehumasan. Keadaan semacam ini mengakibatkan kefatalan ganda, yakni: disatu sisi institusi humas menjadi buta, tidak mengetahui perkembangan yang terjadi dalam lingkungan internalnya, disisi lain humastidak mampu mengembangkan "analisis kritis"nya karena terpaksa atau dipaksa keadaan, sehingga keberadaannya seperti tidak ada. ${ }^{2}$

Manajemen hubungan masyarakat dalam menjalin kerjasama yang eratdengan para tokoh masyarakat termasuk pemimpin formal masyarakat dalam rangka membina pendidikan di madrasah sangat diperlukan, walaupun kerjasama itu tidak selalu mudah diwujudkan, sebab banyak hal lain yang lebih penting bagi masyarakat untukmereka perhatikan.

Kegiatan manajemen hubungan masyarakat mencakup fungsi-fungsi pokok manajemen secara umum: perencanaan, pengorganisasian, kepemimpinan, penyusunan kepegawaian, pengkomunikasian, pengawasan dan penilaian. Hal tersebut bersumber dari definisi manajemen hubungan masyarakat yang berfungsi dan bertujuan menciptakan dan mengembangkan persepsi terbaik bagi suatuorganisasi lembaga pendidikan yang kegiatannya langsung ataupun tidak langsung mempunyai dampak bagi masa depan organisasi lembagapendidikan itu. ${ }^{3}$

Dengan demikian madrasah harus bisa menjadi mercu penerang bagi masyarakat. Sebagai mercu penerang, madrasah harus mampu memberikan tauladan tentang cara

\footnotetext{
${ }^{2}$ Redi Panuju, Krisis Public Relations (Yogyakarta: Pustaka Pelajar, 2002), 5.

${ }^{3}$ Rosady Ruslan, Manajemen Public Relations \& Media Komunikasi (Jakarta: PT. RajaGrafindo, 2003), 31 .
} 
hidup yang benar kepada masyarakat, sehingga masyarakat menjadi berdaya. Pada saat yang sama madrasah harus menampung semua aspirasi dan kondisi masyarakat lokal dengan membuat program pendidikan yang sesuai dengan masyarakat. ${ }^{4}$

MA At-Tahzib Kekait adalah salah satu madrasah di Gunungsari. Predikat favorit yang disandang membuat sebagian besar masyarakat menginginkan putra-putri mereka untuk melanjutkan sekolah di MA At-Tahzib Kekait Gunungsari tersebut. Kepercayaan dan reputasi itu tentu harus mampu dijawab oleh madrasah dengan memberikan layanan pendidikan yangbermutu, serta pengelolaan madrasah yang transparan, akuntabel, dan demokratis. Kondisi tersebut tercapai antara lain karena adanyajalinan komunikasi yang efektif antara madrasah dan masyarakat. MA At-Tahzib KekaitGunungsari terbuka terhadap segala bentuk kritik danaspirasi dari masyarakat, sehingga program pendidikan yang ditawarkan madrasah sesuai dengan kebutuhan dan aspirasi masyarakat.

Sebagai contoh aspirasi didapat dari komite sebagai fasilitator masyarakat, yang seringmenjalin kontakdengan madrasah melalui pertemuan bulanan. Pertemuan komite madrasah dengan orang tua siswa sering diadakan sebagai sarana silaturahmi dan melihatkondisi/keadaan madrasah, yang didalamnya saling bertukar informasi dan setiap ada ide baru, aspirasi dan tuntutan masyarakat yang berkaitan dengan pendidikan madrasahselalu diinformasikankepada madrasah begitu pula sebaliknya. Kemudian informasi tersebut disampaikan kepada kepala madrasah untuk ditindak lanjuti, kepala madrasah memanggil wakil kepala madrasah, bidang kesiswaan, waka kurikulum, waka sarana prasarana, dan waka humas, untuk merancang program yang akan dilaksanakan, setelah itu kepala madrasah menginformasikan hasilrapatnya dengan wakil kepala madrasah kepada semua guru, karyawan, siswa, orang tua siswa, serta komite madrasah. Barulah dialokasikan tugas dan tanggung jawabnya pada masing-masing yang bersangkutan.

Begitupun dengan kegiatan hubungan masyarakat yang dibantu oleh alumni, lembaga swadaya masyarakat, pemerintah, dan komite madrasah serta siswa-siswi madrasah dalam bentuk kegiatanseminar, bazar, penyuluhan masyarakat, pengajian dan bakti sosial, ini merupakanbentuk komunikasi langsung yang dilakukan humas kepada masyarakat untuk menggugah partisipasi masyarakat dalam rangka memberikan layanan yang baik, selain itu juga melalui surat,telepon dan tatap mukalangsung. Untuk mengevaluasi kegiatan maka setiap tahun diadakan rapat pleno untuk membahas kegiatan dan pertanggung jawaban kepalamadrasah, kepada masyarakat.

Oleh karena itu, peneliti tertarik untuk melakukan penelitian secara lebih mendalam dengan judul "Manajemen Hubungan Masyarakat dalam Meningkatkan Partisipasi Masyarakat Sekitar di MA At-Tahzib Kekait Gunungsari”.

\footnotetext{
${ }^{4}$ Made Pidarta, Manajemen Pendidikan Indonesia (Jakarta: PT. Bina Aksara, 1988), 192-193.
} 


\section{METODE PENELITIAN}

Untuk bisa memahami proseskomunikasi yang terjadi antara madrasah dan masyarakat, diupayakan menemukan dan menggambarkan bagaimana proseskomunikasi itu berlangsung. Untuk bisa memperoleh gambaran yang sebenarnya, baik proses terjadinya komunikasi maupun faktor-faktor yang mendasari perilaku komunikasi madrasah dengan masyarakat, maka penelitian ini dilakukan dalam setting yang natural. Untuk itu diperlukan jenis pendekatan penelitian yang bersifat naturalistic sehingga mampu menjelaskan bukan hanya surface behaviour, tetapi juga mampu menjelaskan inner perspective behaviour yang mendasari dan menjadi satu dengan perilaku manusia dan fenomena sosial yang nyata. ${ }^{5}$ Pendekatan penelitian yang seperti ini disebut penelitian kualitatifyang berparadigma alamiah dalam setting yang wajar yang sangatmenekankan pada manusia sebagai instrument utama penelitian dengan data yang bersifat kualitatif, deskriptif, dan holistik.

Pendekatan kualitatif naturalistik inidilakukan untuk mengetahui secara mendalam kondisi sebuah objek dalam setting yang sebenarnya. Pertimbangan lainnya yangmendasari pemilihan pendekatan kualitatif sebagi pendekatan yang digunakan dalam penelitian ini adalah kerena penelitian ini bertujuan untuk memahami keadaan yang terbatas jumlahnya, namun dengan fokus yang mendalam dan terperinci. Partisipasi masyarakat dalam menyelenggarakan pendidikan disebuahmadrasah berjumlah terbatas tetapi kompleks karena itu pendiskripsian secarakualitatif dipandang lebih cepat, disamping itu kumunikasi yang dilakukan antara manajer humas dengan masyarakat adalah proses yang kompleks karena keefektifan komunikasi dipengaruhi oleh faktorfaktor psikologis komunikasi. ${ }^{6}$

Dalam sebuah penelitian kualitatif, instrumentpenelitiannya adalahpeneliti sendiri. Terminology humaninstrument mengandung makna bahwa hampir semua bahkan selalu, peneliti kualitatif melakukan kerja lapangan secara langsung untuk mengumpulkan data penelitian. Keharusan peneliti sebagai instrument penelitian dalam penelitian kualitatif disertai dengan keharusan menggunakan wawancara mendalam sebagai metode dalam pengumpulan data yang paling utama,disamping observasi partisipanbertujuan untuk bisa mengetahui langsung tentang subyek penelitian, maksudnya ketika kepala madrasah melakukan komunikasi dengan masyarakat, pada waktu melakukan rapat pertanggung jawaban dan evaluasi program madrasahMA At-Tahzib Kekait Gunungsari, peneliti turut serta mengikuti dan menyaksikan langsung rapat tersebut sehingga peneliti mengetahui bagaimana proses dan hasil dari rapat tersebut serta mengetahui bagaimana hubungan madrasah dengan masyarakat (partisipasi masyarakat tarhadapmadrasahMA At-Tahzib Kekait Gunungsari). Disamping itu juga pengumpalan data berdasarkan dokumendokumen yang ada, yaitu dukumen pribadi dan dokumen resmi. Dokumen pribadi adalah

\footnotetext{
5 Sanafiah Faisal, Penelitian Kualitatif, Dasar-Dasar dan Aplikasi (Malang: Yayasan Asah Asih Asuh, 1990), 25.

${ }^{6}$ Jalaluddin Ahmad, Psikologi Komunikasi (Bandung: Remaja Rosdakarya, 2001), 25.
} 
catatan atau karangan seseorang secara tertulis tentang tindakan, pengalaman, dan kepercayaannya, seperti bukuharian, agenda, dan lain-lain. Sedangkan dokumen resmi terdiri dari memo, pengumuman, instruksi, aturan suatu lembaga masyarakat, pernyataan dan berita yang disiarkan oleh media massa. ${ }^{7}$

Analisis data yang lebih intensif selanjutnya dilakukan setelah proses pengumpulan data selesai dilakukan. Analisis data adalah proses pengorganisasian dan pengurutan data kedalam pola, kategori, dan satuan uraian dasar sehingga dapat ditemukan tema dan dapat dirumuskan hipotesis kerja seperti yang disarankan oleh data. ${ }^{8}$ Melalui analisis data ini dapat ditemukan pola hubungan antar unsur dalam data deskriptifdengan memperhatikan tiga hal, pertama reduksi data, yaitu upaya perampingan dan pemilihanterhadap data untuk menemukan mana data yang penting dan mana data yang tidak penting, yang penting dipertahankan dan yang tidak penting dibuang, ${ }^{9}$ kedua display data(penyajian data) yang berwujud cerita atau narasi, ${ }^{10}$ dengan menggunakan model naratif deskriptif. Model naratif adalah penyajian data dalam bentuk gambaran dan cerita tentang fokus penelitian, dan ketiga verifikasi data, usaha untuk melakukan pengecekan terhadap kesimpulan yang diperoleh dari kegiatan analisis data, yang pada akhirnya menghasilan kesimpulan yang mantap. ${ }^{11}$

\section{HASIL DAN PEMBAHASAN}

Pada pembahasan initemuan penelitian dianalisisberdasarkan pada perspektif penelitian atau kerangka teoretik dan dibahas secara berurutan sesuai dengan fokus penelitian mengenai konsepmanajemen hubungan masyarakat di MA At-Tahzib Kekait Gunungsari,kondisi umum bentuk partisipasi masyarakat di MA At-Tahzib Kekait Gunungsari, dan model peran manajemen humas dalam meningkatkan partisipasi masyarakat sekitar di MA At-Tahzib Kekait Gunungsari.

\section{Konsep Manajemen Hubungan Masyarakat di MA At-Tahzib Kekait Gunungsari}

Manajemen hubungan masyarakat di MA At-Tahzib Kekait Gunungsari dilakukan dengan menjalin kerjasama yang eratdengan para elemen masyarakat termasuk pemimpin formal masyarakat dalam rangka membina pendidikan, mulai dari orang tua siswa, komite madrasah,tokoh masyarakat, alumni, LSM, pemerintah, madrasah atau sekolah lain.Disamping itu manajemen humas juga difungsikanuntuk memperlancar arus komunikasi internal madrasah dalam rangka menunjang kegiatan madrasah. Seperti yang ditemukan diMA At-Tahzib Kekait Gunungsari bahwa humas ditekankan pada dua aspek, pertama, menjalin komunikasi dengan masyarakat luar madrasah, kedua, menjalin komunikasi internal madrasah. Maka manajemen hubungan madrasah dengan masyarakat

\footnotetext{
${ }^{7}$ Laxy Moleong, Metodelogi Penelitian Kualitatif(Bandung: Remaja Rosdakarya, 2002), 67.

${ }^{8}$ Ibid., 65.

${ }^{9}$ Yatim Rianto, Metode Penelitian, 27.

10 Ibid., 29.

${ }^{11}$ Ibid., 31.
} 
dimulai dari pembenahan organisasi internal manajemen humas hingga kegiatan bersifat membangun citra pendidikan, citra cermin, citra serba aneka lain sebagainya.

Manajemen humas pendidikan membantu memelihara aturan bersama melalui saluran komunikasikedalam dan keluar, agar tercapai saling pengertian atau kerja sama antara madrasah dengan masyarakat. Termasuk di dalamnya mengidentifikasikan dan menanggapi opini masyarakat yang sesuai atau tidak dengan kebijakan yang dilaksanakanoleh lembaga pendidikan yang bersangkutan. Dan juga membantu fungsimanajemen humas dalam mengantisipasi dan memanfaatkan berbagai kesempatan, serta tantangan atau perubahan yang terjadi di dalam masyarakat.

Dalam merencanakan sebuah progam kegiatan madrasah, tak terkecuali unit humas, kepala madrasah memanggil wakil kepala madrasah bidang kesiswaan, kurikulum, humas untuk merancang program yang akan dilaksanakan tersebut.Setelah itu, kepala madrasah menginformasikan hasil rapatnya dengan wakilkepala madrasah kepada semua guru dan karyawan madrasah serta siswa.

Setelah warga madrasah menerima informasi tentang program yang akandilaksanakan oleh madrasah, barulah dialokasikan tugas dan tanggung jawabyang akan dilaksanakan oleh masing-masing warga madrasah. Untukmelaksanakan program kegiatan, masing-masing ditugaskan untuk melakukanpekerjaan tertentu. Begitupun halnya dengan unit humas madrasah memfasilitasikomunikasi internal madrasah dan melakukan komunikasi untuk menjalin hubungan masyarakat dengan masyarakat. Sebagaimana dalam temuan bahwa tugas kehumasan itu menyampaikan informasi kepada masyarakat,bukan hanya masyarakat eksternal madrasah, tetapi juga masyarakat internal madrasah.Tugas Humas selanjutnya adalah memperlancar komunikasi antara madrasah dan masyarakat didalam madrasah dan di luar madrasah, dari luar humasharus mampu menyampaikan umpan balik dari masyarakat danmenyampaikan umpan balik dari masyarakat ke madrasah.

Komunikasi internal dan eksternal inilah sesungguhnya yang diperankan dalam manajemen humas di MA At-Tahzib Kekait Gunungsaridimana pendidikan berperan membantu memelihara aturan bersama melalui saluran komunikasikedalam dan keluar, agar tercapai saling pengertian atau kerja sama antara madrasah dengan masyarakat. Termasuk di dalamnya mengidentifikasi dan menanggapi opini masyarakat yang sesuai atau tidak dengan kebijakan yang dilaksanakanoleh lembaga pendidikan yang bersangkutan. Dan juga membantu fungsimanajemen humas dalam mengantisipasi dan memanfaatkan berbagai kesempatan, serta tantangan atau perubahan yang terjadi di dalam masyarakat.

Komunikasi internal dan eksternal madrasah didukung oleh suasana kerja yangkondusif yang ditandai oleh kenyamanan dan betahnya warga madrasah berada di madrasah. Terciptanya iklim organisasi yang kondusif ini, bukan hanyakebebasan untuk 
mengeluarkan pendapat saja yang diberikan kepada setiapwarga madrasah. Lebih dari itu, setiap warga madrasah diberikan kebebasanuntuk berkreasi, termasuk siswa.

Ketika siswa melakukan pemilihan ketua OSIS, siswa diberikebebasan untuk mempersiapkan semua keperluan untuk melakukanpemilihan, mulai dari menentukan dan menyelesaikan mana yang berhakmenjabat ketua OSIS. Peran guru dan kepala madrasah serta pembina OSISadalah partisipan dalam pemilihan serta fasilitator dalam memperlancarjalannya pemilihan tersebut.

Dari hasil temuan diatas, dapat dinalisa dan disimpulkan bahwa semua warga madrasah terlihat akrab dalam komunikasi formal dan komunikasi informal. Ketika kepala madrasah menginformasikan sebuah kebijakan kepada bawahannya, komunikasi yang terlihat lebih kepada bentuk komunikasi informal, sehingga yang terlihat adalah sebuah hubungan kekeluargaan. Begitu pula yang terjadi dalam kaitannya dengan komunikasi antara para guru. Pilihan kata serta gerak tubuh yang mereka perlihatkan menyiratkan kedekatan hubungan mereka.

Untuk memberikan tugas dan wewenang kepada bawahannya,kepala madrasah berkomunikasi dengan bawahannya. Sebaliknya, untuk memberikan umpan balik kepada kepala madrasah, bawahan berkomunikasi dengan kepala madrasah. Dalam komunikasi organisasi, kelancaran informasi merupakan sesuatu yang harus tercipta untuk menunjang fungsi-fungsi manajemen seperti perencanaan, pengorganisasian, pengarahan,maupun pengendalian. Dalam perencanaan,kepala madrasah tidak bisa bekerja seorang diri, melainkan membutuhkan informasi dan saran dari bawahannya.

Dalam melakukan pengorganisasian, kepala madrasah menginformasikanjenis tugas dan tanggung jawab yang harus dilaksanakan oleh bawahannya. Dalam melakukan pengarahan dan penggerakan (actuating), kepala madrasah bisa mempengaruhi bawahannya untuk melakukan tugasnya dengan efektif dan efisien. Demikian pula dalam melaksanakan fungsikontrol, kepala madrasah membutuhkan komunikasi tentang kinerjabawahannya dan umpan yang diperlukan untuk memperbaiki kinerja tersebut.

Intinya, komunikasi organisasi menentukan sebarapa jauh fungsi manajemen dilakukan secara efektif dalam sebuah madrasah.Dalam kenyataan yang ada di MA AtTahzib Kekait Gunungsari, kepala madrasah selalu melibatkan bawahannya dalam melakukan perencanaanprogram pendidikan yang akan diberikan kepada masyarakat. Demikian puladalam hal penyampaian umpan balik, kepala madrasah selalu menyempatkandiri untuk menerima saran dan kritik dari bawahannya, sehingga semuabawahannya guru-guru dan karyawan tata usaha merasa diharagai danmenjadi bagian dari sukses yang telah diraih madrasah.

Kelancaran komunikasi internal madrasah menyebabkan semua orangmerasa dihargai dan merasa diperlukan di madrasah dengan diterimanya sarandan menjadi bagian dari sukses yang diraih madrasah. Karena rasa memilikitersebut, semua warga madrasah merasa ikut bertanggung jawab terhadapsuksesnya program pendidikan di 
madrasah.Kelancaran komunikasi internal madrasah diartikan sebagai kebebasanuntuk mengeluarkan pendapat dan "uneg-uneg" dari semua warga madrasah.

Kebebasan mengeluarkan semua "uneg-uneg" itu diwujudkan melaluisejumlah kreasi yang selalu dipublikasikan melalui media komunikasi internal madrasah. Dengan demikian, kebebasan berpendapat dan mengeluarkan "uneg-uneg"itu menyebabkan semua warga madrasah merasa memiliki kesempatanuntuk berkreasi. Dalam berkreasi, siswa mendapat kesempatan untukmempublikasikan hasil kreasinya kepada warga madrasah.

Demokratisnya sebuah madrasah bisa dilihat dari kebebasan setiap individu untuk mengeluarkan pendapatnya. Iklim organisasi yang kondusif memberikan kesempatan kepada semua anggota organisasi untukberpartisipasi dalam penyampaian pendapat dan saran. Namun begitu, kelancaran komunikasi internal bukan tanpa dampaknegatif, yaitu kemungkinan terciptanya kondisi yang menyebabkan pimpinan kebanjiran informasi dan semakin derasnya grapevine. Untuk menghindari kondisi pimpinan kebanjiran informasi, MA At-Tahzib Kekait Gunungsari menetapkan saluran-saluran informasi berupa papan pengumuman, majalah dan bulletin internal madrasah, selain media komunikasi tatap muka secara langsung dan layanan telepon 24 jam.

Melalui media ini,pimpinan menampung semua informasi yang ada dan mempergunakannyaketika diperlukan. Di samping itu, wakil kepala madrasah urusan humas danwakil kepala madrasah urusan kesiswan adalah pihak-pihak yang berperan sebagai penampung informasi dari siswa dan semua warga madrasah. Sedangkan untuk menghindari dan meminimalkan dampak derasnya grapevine yaitu mengalirnya informasi dari sumber yang tidak jelas, tetapidari desas-desus atau kabar angin kepala madrasah selalu memberikan informasikepada bawahannya melalui rapat-rapat madrasah dan melalui media komunikasi yang ada sehingga semua warga madrasah menerima informasisecara cepat dan akurat. Tetapi, madrasah sering mengunakan grapevine untuk menyampaikan informasi tentang prestasi madrasah kepada semua warga madrasah, di samping melalui saluran informasi resmi yang telah disediakan.

Humas berperan menyediakan saluran komunikasi dan memfasilitasikelancaran informasi di lingkungan internal organisasi. Humas internal MA At-Tahzib Kekait Gunungsari telah menyediakan beberapa saluran informasi resmi berupakomunikasi tatapmuka, majalah dinding,papan pengumuman, dan sebuahbulletin internal layanan telepon 24 jam. Pemanfaatan saluran informasi yangtelah disediakan dilakukan setiap saat sehingga informasi mengalir lancar dilingkungan internal madrasah.

Dengan demikian, dapat dikatakan bahwa humasinternal MA At-Tahzib Kekait Gunungsari telah berhasil memfasilitasi kelancarankomunikasi di lingkungan madrasah, baik komunikasi formal dari atas kebawah, dari bawah ke atas, maupun komunikasi sejajar di antara karyawan madrasah. Sedangkan komunikasi informal madrasah telah berhasil menciptakanhubungan yang harmonis di antara semua warga madrasah serta 
iklim kerjayang kondusif melalui kebebasan mengeluarkan pendapat dan manajemenpartisipatif.

\section{Kondisi Umum Bentuk Partisipasi Masyarakat di MA At-Tahzib Kekait Gunungsari}

Dalam penyelenggaraan pendidikan, peranserta masyarakat sangat penting, sebagai salah satu elemen pendukung terwujudnya pendidikanberbasis masyarakat, sehingga manfaatkehadiran pendidikan benar-benar dirasakan masyarakat. Salah satu bentuk peranserta masyarakat adalah melakukan pemberdayaan masyarakat dengan memperluas partisipasi masyarakat dalam pendidikan yang meliputi peranserta perorangan, kelompok, keluarga, organisasi profesi, dan organisasi kemasyarakatan dalam penyelenggaraan dan pengendalian mutu pelayanan pendidikan. Masyarakat tersebut dapat berperan sebagai sumber, pelaksana, dan penggunahasil pendidikan.

Partisipasi masyarakat tersebut kemudian dilembagakan dalam bentuk dewan pendidikan dan komite madrasah. Dewan pendidikan adalah lembaga mandiri yang beranggotakan berbagaiunsur masyarakat yang perduli terhadap pendidikan sedangkan komite madrasah adalah lembaga yang terdiri dari unsur orang tua, komunitas, serta tokoh masyarakat yang peduli pendidikan. Dewan pendidikan berperan dalam peningkatan mutu pelayanan pendidikan, dengan memberikan pertimbangan, arahan dan dukungan tenaga, sarana dan prasarana, serta pengawasan pendidikan dalam tingkat nasional, provinsi, dan kabupaten yang tidak mempunyai hubungan hirarkis. Sedangkan peningkatan mutu pelayanan ditingkat satuan pendidikan dan peran tersebut menjadi tanggung jawab komite madrasah. ${ }^{12}$

Dalam penyelenggaraan pendidikan di MA At-Tahzib Kekait Gunungsari banyakunsur masyarakat yang dilibatkan, seperti orang tua siswa, alumni, tokohtokohmasyarakat, pemerintah, dan jajaran kepolisian, bahkan alumnibanyak sekali berpartisipasi dalam kegiatan madrasah. Merekamenyumbang dana dan melakukan pembinaan kepada siswa dalamkaitannya dengan kegiatan ekstra kurikuler, seperti PMR, Paskibradan unit kegiatan olahraga.

Masyarakat diperkenankan berpartisipasi dalam banyak aspek, sepertipengadaan sarana dan prasarana pendidikan, penetapan kebijakan, kontrolpengelolaan dana madrasah pengadaan dana pendidikan, dan aspek-aspeklainnya. Untuk mencapai akuntabilitas madrasah terhadap masyarakat, komunikasi harus terjalin dengan sebaik mungkin, sebab dengan informasi yang diperoleh melalui komunikasi, masyarakat dan madrasah berusaha untuk saling terbuka satu sama lain. Melalui hal itu tercipta transparansi yang memberikan kepada madrasah kerangka akuntabilitas yang baik. Transparansi dan akuntabilitas pada gilirannya melahirkan rasa saling percaya. Rasa saling percaya timbul manakala perilaku masing-masing pihak bisa diprediksi oleh pihak lain. Untuk bisa diprediksi oleh pihak lain, kedua belah pihak harus bersikap terbuka dan jujur. Sikap terbuka dan jujur inilah yang kemudian melahirkan sikap saling percaya.

\footnotetext{
${ }^{12}$ Choirul Mahfud, Pendidikan Multi Kultural(Yogyakarta: Pustaka Pelajar, 2006), 61-62.
} 
Sikap saling percaya membuat hubungan madrasah dengan masyarakat menjadi harmonis. Keharmonisan ini, jika bisa dipertahankan dalam waktu lama membuahkan rasa saling memiliki (sense of belonging) masyarakat terhadap madrasah. Jika masyarakat sudah merasa memiliki madrasah, makamasyarakatpunakan merasa ikut bertanggung jawab terhadap madrasah. Dengan demikian, maka dukungan masyarakat baik dalam bentuk materi maupun dalam bentuk yang lain lebih mudah diperoleh madrasah.

Dalam membangun sebuah kebersamaan dan komunikasi untukmenciptakan hubungan yang harmonis, diperlukan keterbukaan madrasah terhadap masyarakat. Bentuk transparansi madrasah terhadap masyarakat adalah laporan berkala yang diberikan madrasah kepada komite madrasah dan orang tuasiswa mengenai program-program kegiatan madrasah dan perkembangan perilaku dan kemampuan siswa. Selain itu, transparasi diwujudkan melalui pengelolaan madrasah yang terbuka, seperti dalam temuan bahwa untuk menjamin transparansi pengelolaan, madrasah membuka saluran informasi dan dialog dengan semua pihak: dengan siswa, guru, orangtua siswa dan dengan komite madrasah, mengadakan dialogtentang kenaikan iuran madrasah dengan musyawarah perwakilan kelas yang terdiri dari siswa dan komite madrasah, transparansi keuangan jugadijamin, melalui terbukanya bendahara madrasah untuk bersedia diperiksa pembukuan oleh siswa dan orang tua siswa serta komite madrasah.Setiap tiga bulan sekali, diberikan laporan tentang pelaksanaan program kegiatan madrasah, kadang-kadang juga laporan berkala secara tertulis itu diberikan 6 bulan sekali, tergantung jenisdan bentuk program kegiatan yang dilaksanakan, dan untuk lebih menjamin transparansi, setiap saat madrasah bersedia menerima anggota komite madrasah dan orang tua siswa yang ingin mengetahui perkembangan program kegiatan yang dilaksanakan, juga tentang alokasi dan peggunaan dana madrasah.

Sedangkan untuk menjamin akuntabilitas madrasah terhadap masyarakat, MA AtTahzib Kekait Gunungsari membuka diri untuk menerima saran, kritik, maupun ide-ide. Bentuk akuntabilitas madrasah terhadap masyarakat adalahkesediaan madrasah untuk menindaklanjuti aspirasi dan aspirasi masyarakatdalam bidang pendidikan dengan program pendidikan yang sesuai.

Dalam pelaksanaan program pendidikan, madrasah melibatkan masyarakat berperan sebagai pengontrol, melalui laporan masyarakat kepada komite madrasah. Madrasah mengetahui kekurangan dan penyimpangan yang dilakukannya dalam pelaksanaan sebuah program. Jika laporan masyarakat tentang penyelenggaraan program pendidikan tersebut dianggap berat, komite madrasah melakukan rapat internal untukmenentukan langkah yang diambil dalam menyikapi laporam tersebut. Sedangkan untuk meningkatkan partisipasi masyarakat dalam penyelenggaraan pendidikan, madrasah senantiasa melakukan pengelolaan yang transparan dan melakukan sosialisasi yang terarah dan terprogram kepadasemua stakeholder.

Dengan demikian kondisi umum partisipasi masyarakat dalampenyelenggaraan pendidikan di MA At-Tahzib Kekait Gunungsari dapat dikatakan baik. Indikatornya 
adalah kegiatan masyarakat untuk berpartisipasi cukup tinggi. Dalam pengambilan keputusan, masyarakat terwakili dalam keanggotaan dan pengurus komite madrasah banyak yang memberikan andil melalui bentuknyata saran dan kritik terlontar dalam rapat pleno, penetapan RAPBS. Orangtua siswa sebagai pihak yang paling terkait secara langsung dengan keberhasilan penyelenggaraan pendidikan juga memberikan andil yang tidak kecil dalam upaya peningkatan mutu pendidikan seperti sumbangan dana, sumbangan saran, dan bentuk partisipasi yang lain.

Sementara itu, unsur masyarakat yang lain juga banyak berperan dalam penyelenggaraan pendidikan, baik itu sebagai nara sumber, pembina kegiatan ekstrakurikuler, penyumbang dana, penyumbang saran dan kritik, pemberi beasiswa, dan bentuk-bentuk partisipasi yang lain yang tidak kalah pentingnya dalam upaya peningkatan mutu pendidikan.

Dari hasil temuan diatas dapat dianalisis bahwa dengan adanya peran serta masyarakat dalam berbagai aspek mulai dari menjadi pembina kegiatan ekstrakulikuler, menjadi penyumbang dana dan material bangunan, pemberian bea siswa, dan sejumlah bentuk partisipasi lainnya, ini lebih menjadi suatu hubungan yang saling menguntungkan antara madrasah dan masyarakat dengan melalui pengelolaan yang baik, yaitu dalam berkomunikasi, madrasah harus bisa memahami kondisi masyarakat, madrasah harus dapat memberikanpelayanan pendidikan yang relevan dengan kebutuhan masyarakat. Dengan begitu citra madrasah di mata masyarakat menjadi baik, otomatis partisipasi masyarakat semakin meningkat.

\section{Model Peran Manajemen Humas Dalam Meningkatkan Partisipasi Masyarakat Sekitar di MA At-Tahzib Kekait Gunungsari}

\section{a. Perencanaan}

Perencanaan merupakan proses pemilihan alternatif dan proses mengaitkan pengetahuan, fakta, imajinasi dan asumsi masa depan, serta formulasi tujuan yang ingin dicapai, perencanaan merupakan proses dimana mengadaptasi dirinya dengan berbagai sumber untuk mengubah lingkungan dan kekuatan-kekuatan internalyang ada di dalam sistem itu sendiri. ${ }^{13}$

Secara umum dapat diuraikan bahwa perencanaan hubungan masyarakat itu terdiri dari semua bentuk kegiatan perencanaan, wujud rencana kerja dan alasan dilakukannya perencanaan kerja, sebagai berikut:

1) Mengefektifkan dan mengefisienkan koordinasi atau kerja sama antara pihak yang terkait.

2) Mengefisienkan waktu, tenaga, upaya, dan biaya.

${ }^{13}$ Endang Soenaryo, Pengantar Teori Perencanaan Pendidikan Berdasarkan Pendekatan Sistem (Yogyakarta: Mitra Gama Widya, 2000), 36-37. 
3) Menghindari resiko kegagalan dengantidak melakukan perkiraan atau perencanaan tanpa arah yang jelas atau kongkret.

4) Mampu melihat secara keseluruhan kemampuan operasional organisasi, pelaksanaan, komunikasi, target, dan sasaran yang hendak dicapai dimasa mendatang.

5) Menetapkan klasifikasi rencarana strategis sesuai dengan kebijakan jangka panjang, rencana tetap yang dapat dilakukan berulang-ulang dan rencana tertentu.

Untuk menjalin hubungan masyarakat dengan masyarakat luar madrasah diperlukan perencanaan agar kegiatan humas menjadi terarah. Perencanaan humas berdasarkan temuan di MA At-Tahzib Kekait Gunungsari melibatkan semuapihak yang terkait dengan program kegiatan yang akan dilaksanakan, seperti, siswa, guru, dan kepala madrasah, wakamad kurikulum, wakamad kesiswaan dan wakamad humas, komite madrasah termasuk di dalamnya orang tua/wali murid siswa dan stakeholders. Hal ini menunjukkan bahwa kegiatan humas yang ditemukan di madrasah selalu dikoordinasikan dengan pihak-pihak terkait di dalam madrasah.

Walaupun kegiatan humas di MA At-Tahzib Kekait Gunungsari berbentuk macam-macam kegiatan, namun tujuan yang ingin dicapai melalui kegiatan humas tersebut pada dasarnya sama, yaitu menumbuhkan keinginan dan kerelaan masyarakat untuk berpartisipasi dan menjalinkerjasama dengan madrasah dalam kegiatan pendidikan yang dilakukan oleh madrasah.

Kegiatan-kegiatan hubungan masyarakat dengan masyarakat berdasarkan temuan diantaranya: penyuluhan tentang bahaya penyalahgunaan narkoba dan zat adotif lainnya oleh jajaran kepolisian, dan kegiatan lainnya yang merupakan program kerja kepala madrasah seperti rapat pertanggungjawaban pelaksanaan, dan evaluasi program, yang mengundang komite madrasah, sosialisasi ujian akhir nasional kepada orang tua siswa yang dilakukan di madrasah dan kegiatan-kegiatan lainnya. Jenis kegiatan lain yang diprakarsai oleh siswa antara lain seminar tentang remaja, bakti sosial, penyuluhan kesehatan oleh dokter,bazaar, kegiatan pengajian yang mengundang tokoh masyarakat sebagai pembicara dan bekerjasama dengan remaja masjid, serta berbagai bentuk lainnya.

Kegiatan humas yang dilakukan MA At-Tahzib Kekait Gunungsari didasarkan pada adanya kesadaran untuk memenuhi kebutuhan akan adanya pendidikan yang seimbang antara kecerdasan intelektual dan kecerdasanyang lain, madrasah memerlukan kerja sama dan partisipasi masyarakat. Kesadaran itu diterjemahkan ke dalam sejumlah usaha untuk menjalin komunikasi dengan pihak luar madrasah.

Dari uraian di atas dapat dipahami bahwa perencanaan kegiatan hubungan masyarakat dengan masyarakat di MA At-Tahzib Kekait Gunungsari dilakukan secara bersama-sama antara kepala madrasah, wakamad kurikulum, wakamad kesiswaan, wakamad humas, guru-guru serta siswa, komite madrasah termasuk di dalamnya orang tua/wali murid siswa dan stakeholders. Perencanaan partisipasif tersebut menyiratkan 
adanya kondisi saling mendukung di lingkungan internal madrasah. Sedangkan untuk melaksanakan kegiatan, madrasah membentuk panitia pelaksana.

Dengan melibatkan semua unsur madrasah kegiatan pembentukan citra madrasah di mata masyarakat menjadi lebih akurat dan terarah, karena semua pihak menyadari bentuksikap dan perilaku serta tampilan mereka di depan masyarakat bisamembentuk citra di mata masyarakat.

Secara lebih khusus, perencanaan hubungan masyarakat denganmasyarakat dalam bentuk komunikasi verbal di MA At-Tahzib Kekait Gunungsari dimulai dari adanya kesadaran tentang pentingnya partisipasi masyarakat dalam penyelenggaraan pendidikan. Kesadaran itu membuahkan usaha madrasah untuk menggalang partisipasi masyarakat melalui jalinan komunikasi madrasah dengan masyarakat. Kesadaran itu pada dasarnyamerupakan bentuk pengakuan terhadap adanya kekurang mampuan yang dimiliki oleh madrasah dalam mengupayakan pendidikan yang bermutu.

Karena itu, kesadaran itu bisa dikatakan sebagai hasil analisis kebutuhan,yaitu adanya kesenjangan antara apa yang ada dan apa yang seharusnya. Bersamaan dengan analisis kebutuhan, perencanaan juga harus mampu menemukan hambatan dan kemudahan yang makin dihadapi oleh organisasi dalam mencapai tujuan yang telah ditetapkan.

Analisis kebutuhan itu ditindaklanjuti dengan serangkaian rencanakegiatan yang telah dilengkapi dengan alat dan metode akan digunakan untuk menumbuhkan minat masyarakat dalam berpartisipasi dan bekerjasama dengan madrasah. Serangkaian rencana tindakan adalah program kerja yang berisi tugas-tugas yang dilakukan oleh setiap orang dilengkapi dengan alat dan metode yang dibutuhkan untuk menyelesaikan tugas.Dengan kebersamaan antara warga madrasah dan masyarakat penyelenggaraan pendidikan berjalan sesuai dengan program yang telah direncanakan.

\section{b. Pengorganisasian}

Pengorganisasian adalah proses pembagi kerja dalam tugas-tugas yang lebih kecil, membebankan tugas-tugas itu kepada orang yang sesuai dengan kemampuannya, dan mengalokasikan sumber daya, mengkoordinasikannya dalam rangka efektifitas pencapaian tujuan organisasi. ${ }^{14}$

Secara singkat kupasan Ernest Dale dalam Hardjito (1997), dapat diartikan bahwa pentingnya pengorganisasian dengan pertimbangan bahwa :

1) Tugas-tugas yang terinci harus dibuat dalam mencapai tujuan organisasi.

2) Seluruh tugas-tugas harus dijabarkan menjadi kegiatan-kegiatan yang secara logis dan sesuai bagi individu maupun kelompok.

\footnotetext{
${ }^{14}$ Nanang Fatah, Landasan Manajemen Pendidikan, 71.
} 
3) Pekerjaan-pekerjaan anggota organisasi harus dikombinasikan secara logis dan efisien.

4) Perlunya pengendalian dan pengawasan untuk meningkatkan efektifitas. ${ }^{15}$

Berdasarkan pernyataan di atas, dapat disimpulkan bahwa pengorganisasian sebagai suatu pekerjaan pembagi tugas, mendelegasikan otoritas, dan menetapkan aktifitas yang hendak dilakukan oleh manajemen humas. Oleh karena itu, dalam pengorganisasian diperlukan tahapan sebagai berikut:

1) Mengetahui dengan jelas tujuan yang hendak dicapai

2) Deskripsi pekerjaan yang harus dioperasikan dalam aktifitas tertentu

3) Klasifikasi aktifitas dalam kesatuan yang praktis. ${ }^{16}$

Pernyataan tersebut, sejalan dengan hasil temuandi MA At-Tahzib Kekait Gunungsari seperti misalnya pembentukan panitia sangat tergantung dari bentuk kegiatan humas yang akan dilaksanakan. Untuk kegiatan yang merupakan inisiatif dari siswa seperti seminar, baktisosial, bazaar, dan kegiatan-kegiatan keagamaan, panitianya kebanyakan diisi oleh siswa. Dalam hal ini, guru bertindak sebagaipembina dan peserta. Serta kepala madrasah sebagai penanggung jawab, sedangkan untuk kegiatan seperti rapat-rapat madrasah dan pertemuankepala madrasah dengan orang tua siswa dan komite, mengadakan kerjasama dengan psikolog, dan penyuluhan yang dilakukan oleh LSM dan pemerintah, panitianya terdiri dari unsur guru, wakil kepala madrasah, kepala madrasah sendiri dan kadang kami menyertakan wakil darikomite madrasah.

Dalam sebuah kegiatan bakti sosial dan bazaar, aktor utamanya adalah siswa. Bazaar itu diadakan atas inisiatif siswa sendiri, dibazar itu, siswasendiri bertindak sebagai panitia yang menjual berbagai macam barangkebutuhan pokok dan lain-lain.

Dari bentuk panitia tersebut, pihak-pihak yang duduk di dalam kepanitiaan sebuah program kegiatan akan melakukan koordinasi dengansemua pihak yang dibutuhkan demi suksesnya kegiatan.

Dengan demikian dapat dianalisis bahwa bentuk pengorganisasian yang sering dilakukan di MA At-Tahzib Kekait Gunungsari adalah panitia pelaksana. Panitia pelaksana terdiri dari orang-orang yang memegang peranan dan tanggungjawab dalam pelaksanaan rencana yang telah disusun. Orang-orangyang duduk di kepanitiaan sebuah kegiatan hubungan masyarakatdengan masyarakat bukan hanya dari kalangan guru dan karyawan tatausaha madrasah, melainkan seringkali siswa menjadi orang yang palingberperan dalam pelaksanaann kegiatan tersebut. Kegiatan-kegiatan sepertiseminar, bazar, bakti sosial, dan penelitian sosial adalah merupakanprakarsa dan inisiatif siswa.

15 Dydiet Hardjito, Teori Organisasi dan Teknik Pengorganisasian (Jakarta: PT. Raja Grafindo Persada, 1997), 74-79.

${ }^{16}$ Siswanto, Pengantar Manajemen (Jakarta: PT. Bumi Aksara, 2005), 73-75. 
Dalam kegiatan yang merupakan inisiatif darisiswa, guru berperan sebagai pembina dan kepala madrasah sebagaipenanggungjawab.

Bentuk kegiatan seperti rapat madrasah dengan komite madrasah, rapatkomite madrasah dengan orang tua siswa, dan kegiatan lainnya yang merupakan program madrasah biasanya dilakukan oleh guru-gurudan pengurus komite madrasah. Pembentukan panitia dilakukan berdasarkan Surat Keputusan Kepala Madrasah setelah mempertimbangkan saran dan masukan dari guru dan wakil kepala madrasah yang ada.

Untuk melaksanakan sebuah kegiatan, kepala madrasah membentuk panitia pelaksana. Pembentukan panitia dilakukan untuk menghindari adanya penolakan dari pihak-pihak yang tidak setuju dengan pelaksanaan kegiatan. Di dalam penitia, setiap anggota memberikan saran dan masukan tentang bagaimana seharusnya rencana dilaksanakan, sehingga setiapanggota merasa mempunyai tanggungjawab terhadap terlaksananya kegiatan. Dengan demikian penerimaan anggota menjadi semakin tinggi bahkan ketika saran dan masukan mereka tidak diterima karena mereka mengetahui latar belakang lahirnya sebuah kebijakan dari panitia yangtelah terbentuk.

Dalam diskusi panitia, setiap anggota akan menyadari bagaimana setiap kegiatan dan saling mendukung satu sama lain. Karena itu, mereka akan semakin menyadari peran dan tanggung jawab mereka dalam implementasi rencana. Berkaitan dengan semakin baiknya koordinasi antaraanggota panitia, panitia merupakan tempat latihan bagi manajer, karena di dalamnya mereka belajar untuk mengambil keputusan, melakukan pengorganisasian dan koordinasi, melakukan kontrol serta evaluasi terhadap kegiatan yang telah dilaksanakan.

Kelebihan lainnya adalah adanya penyebaran kekuasaan sehingga kekuasaan dan wewenang tidak disalahgunakan melalui penugasan. Disamping itu,karena panitia biasanya terdiri dari beberapa orang, kontrol terhadap pelaksanaan kegiatan juga semakin mudah. Panitia juga bisadigunkan oleh manajer untuk meminimalisir dampak gagasan atau saranyang berkonsekwensi negatif melalui penerapan kebijakan secara bijaksana.

\section{c. Pengaktifan}

Pengaktifan bisa juga disebut penggerakan (actuating), pemimpinan (leading), atau pengarahan (directing). Penggerakan dimaksudkan sebagai upaya untuk membuat semua anggota kelompok mau bekerja dan bersedia mengembangkan segenap pikiran dan tenaganya untuk melakukan tugas pekerjaannya dalam rangkamewujudkan tujuan organisasi.

Penggerak atau pemotivasian (pengaktifan) yaitu dapat diartikan sebagi keadaaan kejiwaan dan sikap mental yang memberikan energi mendorong kegiatan, atau menyalurkan perilaku kearah mencapai kebutuhan yang memberi keseimbangan secara 
singkat, pengaktifan sebagai penggerak semua potensi dan sumber daya lainnya agar secara produktif berhasil mencapai tujuan. ${ }^{17}$

Berdasarkan penjelasan di atas memperkuat temuan bahwa pelaksanaan kegiatan hubungan masyarakat dengan masyarakat pada intinya adalah komunikasi madrasah dengan masyarakat kegiatankomunikasi yang dilakukan MA At-Tahzib Kekait Gunungsari dengan masyarakat sudah menjangkau sebagian besar elemen masyarakat. Melalui sejumlah kegiatan yang telah dilaksanakannya. Hubungan masyarakat dengan masyarakat di MA At-Tahzib Kekait Gunungsari telah membentuk semacam jaringankerja yang cukup luas, melalui kegiatan seminar, bakti sosial, bazaar,rapat pertanggung jawaban dan evaluasi program madrasah, penyuluhan darimasyarakat dan bentuk komunikasi melalui surat dan telepon, serta tatap muka langsung, madrasah melakukan kerja sama dan menggugah masyarakat untuk berpartisipasi dalam program kegiatan yang direncanakan. Pihak yang menjadi sasaran komunikasi dalam kegiatan humas yang dilakukan oleh MA At-Tahzib Kekait Gunungsari antara lain orang tuasiswa, pemerintah, LSM, tokoh masyarakat, jajaran kepolisian, komite madrasah.

Setiap tahun komite madrasah bersama madrasah mengadakan rapat pleno untuk membahas pertanggung jawaban kepala madrasah kepada orangtua siswa dan komite madrasah. Rapat pleno tersebut merupakan bentukkomunikasi madrasah dengan masyarakat dalam upaya menggugah minatdan perhatian masyarakat untuk berpatisipasi dalam penyelenggaraan pendidikan. Komunikasi madrasah yang lain dilakukan dengan jajaran kepolisian dan tokoh masyarakat serta pemerintah.

Dengan demikian dapat dianalisis bahwa komunikasi yang dilakukan madrasah dengan masyarakat tersebut bertujuan membentuk citra positif madrasah di mata masyarakat sehingga masyarakat bersedia berpartisipasi dan bekerjasama dengan madrasah dalam meningkatkan mutu pendidikan.Setelah masyarakat memahami program pendidikan yang dilaksanakan madrasah, diharapkan masyarakat memberikan umpan balik kepada madrasah berupa kritik, saran,ide-ide, serta kebutuhan mereka di bidang pendidikan.

\section{d. Pengendalian}

Pengendalian yang dimaksudkan di sini adalah menentukan apayang harus dikerjakan dan apa yang tidak harus mereka kerjakan, dan mengerjakan hal-hal yang telah diinstruksikan. Dan juga mengukur hasil kerja dan campur tangan apabila hasil yang dicapai kurang memuaskan. Pengendalian dalam suatu bentuk jelas perlu untuk mendapatkan kinerja yang terpercaya dan terkoordinasi. ${ }^{18}$

Dalam pengendalian mengukur kearah tujuan tersebut, diperlukan suatu usaha sistematik untuk menetapkan standart kinerja dengan sasaran perencanaan, mendesain umpan balik informasi, membandingkan kinerja aktual dengan standart yang telah

\footnotetext{
${ }^{17}$ Siswanto, Pengantar Manajemen (Jakarta: PT. Bumi Aksara, 2005), 119.

${ }^{18}$ Ibid., 125.
} 
ditetapkan, menentukan apakah terdapat penyimpangan dan mengukur signifikansi penyimpangan tersebut, dan mengambil tindakan perbaikan yang diperlukan untuk menjamin bahwasemua sumberdaya lembaga pendidikan yang sedang digunakan sedapat mungkin secara lebih efisien dan efektif guna mencapai tujuan pendidikan. Berdasarkan batasan diatas terdapat empat langkah pengendalian sebagai berikut:

1) Menetapkan standart dan metode untuk pengukuran kinerja

2) Mengukur kinerja

3) Membandingkan kinerja sesuai dengan standart

4) Mengambil tindakan perbaikan

Dengan demikian pengendalian dilakukan terhadap proses kegiatan, tergantung jenis dan bentuk kegiatannya. Pengendalian kegiatan humas di MA At-Tahzib Kekait Gunungsari dilakukan berdasarkan rencana yang disusun dalam kepanitiaan. Sedangkan apabila terjadi penyimpangan, kepala madrasah sebagai penanggung jawab tertinggi, kegiatan humas dan guru-guru sebagai pembina kegiatan akan memberikan koreksi.

Pengendalin Humas dilakukan untuk menjaga kegiatan agar tetap sesuai dengan rencana. Apabila terjadi penyimpangan, kepala madrasah dan guru akan memberikan teguran dan saran yang semuanya harusberjalan sesuai dengan rencana. Setelah kegiatan selesai para anggotapanitia akan melakukan rapat evaluasi, disanalah kepala madrasah benyak memberikan pengarahan.

Standar yang digunakan untuk mengulur keefektifan kerja humas adalah kerjasama dan pertisipasi masyarakat dalam kegiatan pendidikan. Walaupun kegiatan humas yang dilakukan diMA At-Tahzib Kekait Gunungsariberagam bentuk dan jenisnya. Namun tujuan akhirnya untuk membangkitkan minat masyarakat untuk berpartisipasi dan bekerjasama dengan madrasah.

Salah satu kriteria yang dipakai untuk mengukur keefektifan kerja humas adalah partisipasi masyarakat. Dengan demikian peran manajemen hubungan masyarakat dalam meningkatkan partisipasi masyarakat ditentukan oleh lancarnya komunikasi internal madrasah. Kebebasan guru dan siswa untuk mengeluarkan pendapat menyebabkan mereka merasa telah dan merasa sebagai bagian yang dibutuhkan didalam madrasah.

Kebebasan mengeluarkan pendapat tersebut membuat setiapkreasi yang mereka buat terasa dihargai dan didukung oleh pihak madrasah. Kebebasan berkreasi tersebut pada akhirnya membutuhkan kehadiran masyarakat sebagai pihak yang membutuhkan pelajaran pendidikan. Untuk menghadirkan masyarakat, hubungan masyarakat dengan masyarakat adalah sesuatu yang mutlak diperlukan dengan peran manajemen hubungan masyarakat yang baik, kehadiran masyarakat untukikut berpartisipasi dalam penyelenggaraan pendidikan menjadi lebihmudah dikoordinir sesuai sesuai dengan kebutuhan madrasah. 
Pengendalian di sini dimaksudkan untuk menjaga kegiatan agartetap sesuai dengan rencana yang telah disusun, dan dilakukan pada tiap-tiapkegiatan sesuai dengan jenis dan bentuk kegiatan, yang paling diperlukan adalah pengendalian terhadap proses komunikasi dengan mempersiapkan komunikator, dan pesan yang akan disampaikan kepada masyarakat. Dengan demikian kegiatan hubungan masyarakat dengan masyarakat harus dievaluasi secara berkala dan dengan frekuensi yangrelatif lebih sering, untuk menghindari penyimpangan yang terlalu jauhdari kegiatan komunikasi yang dilakukan madrasah dengan masyarakat.

Dengan adanya pengendalian tersebut proses komunikasi internal madrasah akan menjadi lancar sebagaimana kelancaraan komunikasi internal madrasah sangat mendukung untuk memperlancar semua program madrasah yang diperoleh dari hasil kerjasama atau dari aspirasi masyarakat. Sehingga masyarakat merasa dihargai dengan adanya program-program dari masyarakat yang dilaksanakan.

\section{SIMPULAN}

Berdasarkan pembahasan temuan penelitian, dapat disimpulkan hal-hal berikut:

1. Konsep manajemen hubungan masyarakat di MA At-Tahzib Kekait Gunungsari dimulai dari proses perencanaan, pengorganisasian, pengkomunikasian, dan pengendalian segala bentuk komunikasi madrasah baik denganmasyarakat internal maupun dengan masyarakat eksternal madrasah. Perencanaan dan pengorganisasian humas dilakukan secara partisipatif dengan melibatkan semua unsur madrasah yang terkait dalam kegiatan hubungan madrasah dengan masyarakat, karena itu kelancaran komunikasi internal madrasah memberikan kontribusi terhadap kelancaran komunikasi internal. Pengaktifan hubungan madrasah dengan masyarakat berupa kegiatan komunikasi madrasah dengan masyarakat dilakukan dengan memperlihatkan unsur-unsur komunikasi. Pengendalian kegiatan hubungan madrasah dengan masyarakat dilakukan terhadap proses dan hasil kegiatan hubungan madrasah dengan masyarakat.

2. Kondisi umum bentuk partisipasi masyarakat di MA At-Tahzib Kekait Gunungsari dalam penyelenggaraan pendidikan dapat tumbuh dan berkembang dalam kondisi keterbukaan dan adanya sikap saling percaya antara madrasah dengan masyarakat. Untuk menumbuhkan kondisi keterbukaan dan sikap saling percaya, madrasah perlu menjalin komunikasi dengan masyarakat. Partisipasi masyarakat dalam bentuk pengambilan keputusan, pelaksanaan program, pemanfaatan program, serta evaluasi program madrasah difasilitasi dan dijembatani olehmadrasah yang berfungsi mewadahi aspirasi dan kebutuhan masyarakat serta menggalang dan menyalurkan partisipasi masyarakat dalam bidang pendidikan. Kemampuan komite madrasah melakukan peran dan fungsinya tergantung dari kemampuan komite madrasah dalam memberikan kesempatan kepada komite madrasah untuk melakukan peran dan fungsinya melalui hubungan kemitraan yang sejajar. 
3. Model peran Manajemen Humas dalam meningkatkan partisipasi masyarakat sekitar di MA At-Tahzib Kekait Gunungsari adalah sebagai perencana yaitu dengan terjalinnya komunikasi madrasah dengan masyarakat maka perpaduan ide tentang pendidikan terwujud demi meningkatkan mutu pendidikan yang lebih profesional. Setelah menentukan rencana tindakan yang akan dilaksanakan madrasah adalah pengorganisasian dan pengaktifan yaitu kegiatan untuk menentukan dan mengelompokkan pekerjaan-pekerjaan yang harus dilakukan kedalam unit-unitkerja, membagi-bagi pekerjaan dan menempatkan orang pada masing-masing unit kerja lengkap dengan wewenang dan tanggungjawabnya masing-masing serta menetapkan mekanisme kerja di antara sesama unit kerja yang perlu bagi terwujudnya suatu kerjasama yang efektif. Peran berikutnya adalah pengendalian yaitu untuk menjaga kegiatan agar tetap sesuai dengan rencana yang telah disusun, dan dilakukan pada tiap-tiap kegiatan sesuai dengan jenis dan bentuk kegiatan, yang paling diperlukan adalah pengendalian terhadap proses komunikasi dengan mempersiapkan komunikator, dan pesan yang akan disampaikan kepada masyarakat.

\section{DAFTAR PUSTAKA}

Abdurrahmansyah, Wacana Pendidikan Islam, Khazanah Filosofis dan Implementasi Kurikulum, Metodologi dan Tantangan Pendidikan Moralitas. Yogyakarta: Global Pustaka Utama,2004.

Ahmed, Akbar S. Postmodernism and Islam. New York: Routledge,1992.

Azzet, Ahmad Muhaimin. Urgensi Pendidikan Karakter di Indonesia.Yogyakarta: ArRuzz Media, 2010.

Departemen Pendidikan dan Kebudayaan, Kamus Besar Bahasa Indonesia.Jakarta: Balai Pustaka, 1995.

Fajar, A. Malik et.al. Platform Reformasi Pendidikan dan Pengembangan Sumber Daya Manusia. Jakarta: Logos, 2001.

Goleman, Daniel. Kecerdasan Emosi untuk Mencapai Puncak Prestasi.Jakarta: Gramedia, 1999.

Hitami, Munzir. Mengonsep Kembali Pendidikan Islam. Pekanbaru:Infinite Press,2004.

Hornby, AS. Oxford Advanced Learner's Dictionary of Current English.tt: Oxford University Press, 1995.

Kulsum, Umi. Implementasi Pendidikan Karakter Berbasis PAIKEM (Sebuah Paradigma Baru Pendidikan di Indonesia). Surabaya: GenaPratama Pustaka, 2011.

"Model Pendidikan Karakter Bangsa" dalam http://www.scribd.com/doc/50719355/Model-PendidikanKarakter-Bangsa

Munir, Abdullah. Pendidikan Karakter, Membangun Karakter Anak Sejak dari Rumah. Yogyakarta: Pedagogia, 2010. 
Nata, Abuddin. Manajemen Pendidikan: Mengatasi Kelemahan Pendidikan Islam di Indonesia. Jakarta: Kencana, 2003.

Shimogaki, Kazou. Kiri Islam Antara Modernisme dan Postmodernisme; Telaah Kritis atas Pemikiran Hasan Hanaffi, ter. M. Imam Aziz dan M.Jadul Maula. Yogyakarta: LKiS, 2000.

Sudrajat, Akhmad. "Tentang Pendidikan Karakter" dalamhttp://akhmadsudrajat. wordpress.com/2010/09/15/konseppendidikan-karakter/

Suyatno. "Peran Pendidikan sebagai Modal Utama MembangunKarakter Bangsa" makalah disampaikan dalam Sarasehan Nasional "Pendidikan Karakter" yang diselenggarakan Direktorat Jenderal Pendidikan Tinggi dan Kopertis Wilayah III Jakarta, 12Januari 2010.

Tim Penyusun. Pembinaan Pendidikan Karakter di Sekolah Menengah Pertama.Jakarta: Kementerian Pendidikan Nasional, 2010.

Yani, M. Turhan. "Pendidikan Karakter Berbasis Agama", Makalah,Disampaikan dalam seminar di STAIN Pamekasan pa da tanggal 29 September 2011. 